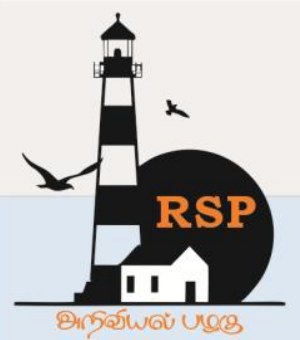

INTERNATIONAL RESEARCH JOURNAL ON ADVANCED SCIENCE HUB

ISSN : $2582-4376$
Open Access

RSP SCIENCE HUB

(The Hub of Research Ideas)

Available online at www.rspsciencehub.com

Special Issue of First International Conference on Advancements in Engineering \& Technology (ICAET- 2020)

\title{
International Marketing in the Modern Era
}

Ahmad A . I. Shajrawi ${ }^{1}$,Nawab Ali Khan ${ }^{2}$

${ }^{1}$ Research Scholar, Commerce Department, Aligarh Muslim University, Aligarh, India

${ }^{2}$ Professor, Commerce Department, Aligarh Muslim University, Aligarh, India

ahmadsej2016@gmaol.com ${ }^{1}$

\begin{abstract}
This paper aimed to explain and define the term of International Marketing and How the firms can have an access to new markets in the world. Also, it focuses on how the marketers create a new strategy to gain new customers at both the local and global levels, and to promote their new products and services. International Marketing is characterized as less costing and using technology( i.e. the social media apps and the internet websites)in promoting the products and services. Several international companies including Amazon company have been ubiquitous all over the world through its website. In 2017, its profit went all the way up to $\$ 3.03$ billion, which means it has penetrated the global markets and achieved its objectives.
\end{abstract}

Keywords : Marketing, Marketing Mix, International marketing

\section{Introduction}

International Marketing is an important term for the states economies of the world. Technology has rapidly made progress and wide spread playing a major role in getting access to new world markets.[1] A large number of multinational companies in the world have developed their strategies to promote their products and services. For example, Pepsi, Coca cola and Hyundai have got a Global reputation, which in turn has shifted their scope from domestic companies to international ones.[2]

\section{Definition of the International Marketing}

The concept of International Marketing is defined as a business or economic activity aiming to sell products and services from one country to another.[5]The International Marketing is also called global marketing. It is the actual implementation and realization of marketing principles in an attempt to achieve needs and desires of different customers across the borders.[6] In other words, the International Marketing is the crucial performance of the actions of marketing in more than one country.

3.Features of International Marketing

The world markets should pursue the entire process of designing, planning, and implementation marketing strategies to achieve the marketing objectives of other countries.[2]

3.1International Marketing has a variety of features which distinguish it from domestic and other types of marketing; and they are as follows:

1)It contains at least two sets of uncontrollable variables.[3]

At the international level, the whole firms face uncontrollable variables from different nations. While establishing business globally, it is most likely that a given firm will deal with these variables.

2) It requires broader efficiency

The international market requires more mastery, 
exceptional management skills and wider competence to best deal with different circumstances and positions such as modifications in the strategies of the government, the mindset of people and many others.[4]

\section{3) High Competition}

Competition encompasses some sort of risk at the international marketing level since the web-based associations are forced to compete nationally and globally as well. The feature of competition is based on the fact that there is a grapple between the developed countries and the developing ones; each has its own economic strategies and unequal disparate competences.[5]

\section{4) It contains hazard and challenges}

The international marketing is subject to various and tangible sort of risk and challenges. These challenges include political restrictions, local and social contrasts, changing design patterns, unexpected war circumstances, amendment in government rules and regulations and communication barriers.[6]

\section{The Importance of Advanced Technology [6]}

The international market is governed by a number of developed industrial nations like the USA, Japan and Germany. They tremendously utilize a highly advanced technology in production, marketing, advertising and building up a brand name. Such nations provide a high quality of products with reasonable costs. Currently, Japanese items have a ubiquitous presence in the business sectors all around the globe. The Japanese model has been undeniably of great success due to computerization and effective use of advanced computer technology.

\section{Differences between Domestic and International Markets}

In the domestic market, currency, language and culture are mostly approximate. There is a little effect of the government interference. the barriers between individuals are almost absent. Moreover, the marketing environment is not complex. In the global market, however, culture, language and currency are different. Governments try to protect domestic markets and industries. the distance barrier and business or marketing environment are largely complex, dynamic and multi-dimensional; differences in legal systems.[3][4]

\section{The merits of International Marketing}

\section{1) Costless}

This arises through technology which helps to promote and advertise new products and services[7]

\section{2)Developed Products and Program efficiency}

It is regarded the most valuable merit of the international marketing strategy. Great ideas are comparatively rare in the business field.[8]

\section{3)Increased Customer Predilection}

The international Marketing Strategy helps to build up a recognition that can increased the customer predilection via reinforcement.[7]

\section{4) Raised Competitive Advantage}

Via integrating resources into a program, the international marketing strategy fosters the competitive driving force of the program as there is a number of competitors wide spreading all over the world and have a strong desire to develop their program to become a high quality one. Using concentrated international marketing strategy allows the smaller companies to compete with larger competitors in a more efficient way.[9]

\section{International Marketing Environment}

1)The Economic Environment: Each state has its own economic factors which in turn have a great impact on the business decisions and activities. There are different prices for products and services, disparate purchasing habits, discrepancy in monetary and fiscal policies, the level of GDP, interest rates, balance of payment business customs and practices, etc. For example, investment is customarily more active in the states with mild tax system than those with severe taxation. The global economic system effects business decisions and global marketing. States which embrace independent market system tend to be more globally and facilitate to have an access to the markets than those that embrace centrally planned system. Penetration into centrally planned economies requires an official government permission, scrutiny and a some sort of 
monitoring and in some cases government interference which may account for some restrictions of the international marketer. 2)Socio-Cultural Environment: This environment encompasses such factors as culture, social make up, language, aesthetics aspiration and value, religion, etc that cultivate the sociocultural identity of specific group of customers. Culture includes concrete and abstract elements. the concrete Cultural elements are the culture sides that can be seen, touched, tasted smelt and heard, e.g. products. However, the abstract parts for a given culture are those cannot be seen, tasted, touched, smelt, but they can be heard like music; therefore, those elements for culture are abstract in nature. Social institutions like universities, worship places, the press, government and its agencies, rivals (age group, clubs) and organizations also impact the costumer' behavioral style. For example, the education level (i.e. literacy level) effects the option 'advertising messages, style of advertising, marketing strategies to be embraced and marketing firms existing at a state.

3)Politico-Legal Environment: The importance of the international marketing environment part lies in the politico-legal factors. The state's political structure and practices as well as its own legal frame of reference largely effect the global marketer's decision. The differences in laws or legal systems lead to variation in business activities. laws regulating business are in charge of enacting the statutes and instructions to practically apply to business registration, ownership, structure and composition, size and business kind (sole proprietorship, partnership, joint stock, and cooperative businesses). At the level of each state, the laws regulate the business practices.[7] A global marketer has to know the laws regulating business activities at the state level before penetrating the global markets.[8]

4)Technological Environment: The widespread of technology effects the production level, innovation and products assortment and services which the marketer has able to make marketing strategies in his country. In the present time, companies have been challenged by using modern or amended techniques in production.[7] The modern techniques motivate the cluster production, innovation, and therefore, major returns to investment will be. For example, the use of computers has replaced thumb manual techniques such as paperwork. Therefore, the use of computer is characterized as rapid, trustworthy, delicate and granting update information regarding stocks. There is technology in the communication domain where various equipment and tools have been improved to facilitate and link communication. Currently, the internet connection, fax, mobile phones, etc. are tremendously made use of. This ensures active communication. It is necessary that the global marketer should pay a close attention to determine the challenges and chances concerning the technological improvement, and better use such tools .

\section{Marketing Mix}

Marketing mix is an integral part of the process of making marketing decisions.[5] They form all marketing activities and performance.[6]The marketing mix encompasses product, price, place and promotion. In the previous section, a discussion of these 4Ps have been presented, and the process of decision making will be only highlighted in the following section.[7]

$>$ Product: it contains the following domains: quality, packaging, features, labeling, sizes, brand name, service, product policy, designing and using.[5]

$>$ Price: it includes the following domains: price list, discount, payment time, credit conditions and allowances, price policy, strategies and methods. Factors impacting price in global marketing are government laws, competition, the buyer's level of disposable income, demand elasticity of the product, nature of the market, production cost, pricing purpose.[6]

> Place (it is called distribution): it includes the following fields: distribution channel, place and covering, inventory, transportation, shops, etc.[7]

$>$ Promotion: it encompasses sales promotion, public relations and publicity, personal selling, advertising.[8]

\section{International Marketing Channels}

The concept of channel is lane that permits the incidence of certain processes.[9] Marketing channels support the exchange process to pick 


\section{www.rspsciencehub.com}

place. The marketing channel is a set of reciprocal relationships with originate customer value, consuming and disposing of goods and services. International marketing includes coordinating the company eno naht erom ni seitivitca gnitekram $\mathrm{s} \square$ country.[3] The international marketing strategy is efficiently substantiated by choosing the appropriate international marketing channel.[4] The channel is the median through which the company si ygetarts gnitekram lanoitanretni $\mathrm{s} \square$ transferred among the customers all around the world.[5]

Marketing channels are a set of interrelated companies involved in the process of making goods and services available for using or consumption.[7]

A major focus of the channels of distribution is upon delivery. It is only during distribution that public and private products and services can be made available for using or consumption. The emergence and management of a wide diversity of distribution oriented institutions and organizations typically,[8] called intermediaries as they stand between productions on one hand and consumption on the other can be interpreted in the following expressions[9]

1)Intermediaries can develop the efficiency of the process.

2)They can be of benefit in the proper management of routes of transactions .

3)They can help in the searching process.

4)They can be of a great value in the rating or classification process.

Internationally operating firms have a partnership with distributors in order to access to their own experience and knowledge.[6] Channel invention relies on several factors such as economic level improvement for the state that the company is operating, domestic demographic/ geographic variables, social norms, government activities and competitive.[7] A properly designed distribution channel can assist a firm to gain a sustainable competitive advantage. Channels form changes in cooperation with the customer.

\section{References}

[1].Awoniyi,M,A.(1999).International Marketing, Obafemi Awolowo University, LLe-Lfe

[2].Gaikwad,Shubhangi.(2017). Features of International Marketing; International Journal
Volume 02 Issue 11S November 2020

of latest Technology in Engineering ,Management \& Applied Science(IJLTEMAS)

[3].George S, Yip.(1992). Total Global Strategy : managing for Worldwide competitive Advantage, Englewood Cliffs, NJ :Prentice Hall

[4]. Ghauri,Pervez,Cateora,Philip.(2013). International Marketing, Edinburgh,Business School, Heriot-Watt University

[5].Kotler, P , Armestrong , G.(2005). Principles of Marketing , $11^{\text {th }}$ Edition , New York: Prentice Hall

[6].Kotler , P , Keller , K.(2016). Marketing Management, $15^{\text {th }}$ global edition , Pearson education limited 2016

[7].Kozak , Yuriy ,Smyezek , Slawomir.(2015). International Marketing, University of Economics, University of economics, KievKatowice, CUL

[8].Lakshmi , Y . P.(2014). International Marketing , Department of Management Studies , Jawaharlal Nehru Technological University, Anatapur, CREC

[9].Philip . R , Cateora.(2007). International Marketing, MC .Graw-Hill , International Edition, Chicago 